\title{
Erratum to: Learn Ionic 2
}

\author{
Joyce Justin and Joseph Jude
}

\section{Erratum to:}

J. Justin and J. Jude, Learn Ionic 2, https://doi.org/10.1007/978-1-4842-2617-9

The book was inadvertently published with an incorrect copyright holder of captioned title as "The Editor(s) (if applicable) and The Author(s)" whereas it should be "Josephine Eskaline Joyce Justin and Joesph Xavier Judes". The copyright holder has been updated in the book.

The updated original online version for this book can be found at https://doi.org/10.1007/978-1-4842-2617-9 